
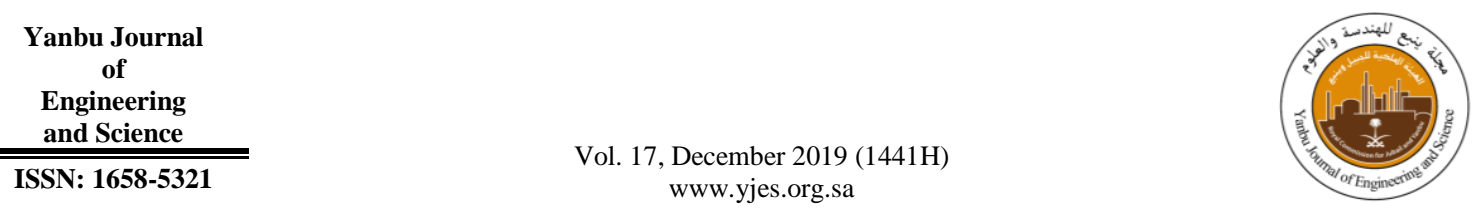

\title{
OPTIMIZATION AND SIZING OF AN ISLAND MICROGRID BASED ON PHOTOVOLTAIC/FUEL CELL (PV/FC) IN KSA
}

\author{
M. M. Samy ${ }^{1 *}$ and K. A. Alkhuzai ${ }^{2}$ \\ ${ }^{1}$ Electrical Engineering Department, Beni-Suef University, Beni Suef, Egypt. \\ *Electrical Engineering Department, Faculty of Engineering, Albaha University, Albaha, \\ Kingdom of Saudi Arabia. \\ ${ }^{2}$ Civil Engineering Department, Faculty of Engineering, Albaha University, Albaha, \\ Kingdom of Saudi Arabia. \\ E-mail: mohamed_227@hotmail.com
}

\begin{abstract}
The major goal of this research manuscript is to conduct economical and feasibility studies of an island photovoltaic/fuel cell (PV/FC) hybrid system. It has been designed to feed electricity to a remote area positioned in albaha zone in Kingdom of Saudi Arabia. To achieve this mission, all system devices are modelled and simulated via optimization mechanisms. An objective function is formulated relied on the total annual cost (TAC). An optimization mechanism, the Flower Pollination Algorithm (FPA) has been applied to obtain the optimum number of the photovoltaic (PV) panels, the electrolyzers; the $\mathrm{H}_{2}$ storage tanks the fuel cells (FCs) and the number of batteries for the proposed system with the least total net present value (TNPV) of the hybrid system. The loss of power supply probability (LPSP) has been utilized to improve the performance of the proposed system. The premier estimation fluctuation effect of the $\mathrm{FC}$, the electrolyzer and the $\mathrm{H}_{2}$ storage tanks on the levelized cost of energy (LCOE) has been applied in the sensitivity test.
\end{abstract}

Keywords: Solar photovoltaics, Fuel Cells, Optimization Mechanisms, Flower Pollination Algorithm, Total Net Present Value, LPSP, Artificial Bee Colony, Kingdom of Saudi Arabia.

\section{INTRODUCTION}

In developing nations, provincial areas suffer from drastic shortage of electricity, where it is not economically feasible to connect these areas to the electrical utility. The insufficiency of electrical power supply has led to the mitigation of economic progress in these regions. The most commonly proposed solution of this problem is to install off-grid renewable energy systems [1]. Recently there has been significant mitigation in the estimate of these technologies as due to technological progress within them, as well as government policies that encourage to utilize these technologies. In KSA, SEC is obliged to buy the generation of renewable resources at the prices stated by the cabinet of ministers through PPA for time interval of twenty five years for PV and wind projects. The reliability of the hybrid system design is based on true combinations of renewable energy sources, and depends on the climatic conditions of the studied area, as well as the initial cost of the components of system. To reach an optimal solution, extensive studies need to be carried out. In the proposed study the

Received: 17 November 2018, Accepted: 13 January 2019 
solar radiation and hydrogen resource data of the study area were used in order to develop the optimal sizing model according to LPSP and EXC [2-6]. Designing dynamic system requires promotion optimization mechanisms to reach the optimal grouping of renewable resources that consider the mention measures. Previous manuscripts have been focused on utilizing evolutionary algorithms. Kalantar et al [7] utilized GA to mitigate the annual cost of an off-grid PV/wind/micro-turbine system with battery storage. Koutroulis et al [8], also has been developed the GA to obtain the optimal size of isolated hybrid system while achieving the least cost. Singh et al [4], proposed the ABC algorithm to perform an economical study of hybrid PV/wind/biomass system, the proposed algorithm results has been verified compared with HOMER package and the PSO algorithm results. Paliwal et al [9] has been presented a systematic technique for determining an optimal mix of resources for an autonomous power system. The PSO has been applied to determine the optimal component sizing. Sharafi et al [10], have been proposed multi objective PSO approach to optimize the size of hybrid system based on the $\varepsilon$ constraint method which has been applied to reduce the system cost, unmet load and GHG emissions. Tahani et al [11] optimized the PV/Wind/Battery remote system, using hybrid FPA/SA algorithm. Oda et al [12] applied FPA approach for the planning of distributed generators and to enhance the voltage stability of the system. The FPA has been succeeded for testing the PV parameters assessment, it has been demonstrated to be an efficacious optimization method in multi objective optimization of isolated micro grids [13] compared with non-overpower sorting GA. Fortunately, rural areas in KSA have abundant solar power (14) and biomass sources used in constituting hybrid island off-grid systems for meeting their energy needs. Recently mix of solar and wind with FC has been received worthy awareness. Dash \& Bajpai [15] have progressed a power management control planning for isolated PV/FC/battery system, while Saravanan \& Thangavel [16] have submitted energy management system depending on immediate reference existing project for the PV/Wind/FC system. Chen [17] has proposed an arrangement of solarhydrogen mild FC systems for the electric vehicles. Bezmalinovi et al [18] have leaded a techno-economic analysis of the PEM FCs with PVs for the distant base stations. This work introduces really approach of an optimal island system qualified for feeding electric power to rustic district in KSA. The system is consisting of PV arrays and FCs. The FPA approach is used to select the capacity of the solar PV, PEM FCs, electrolyzers and hydrogen storage tanks. The selection is based upon reducing TNPV of the system for a specified LPSP and EXC using FPA. The FPA is applied due to its effectiveness and few parameters required compared to other optimization techniques which makes it easier to implement and simulate [19].

\section{PORPOSED HYBRID SYSTEM MODEL}

The proposed system is shown in Figure 1. The surplus energy that exceeds the load is then used to charge the electrolyzers which produces $\mathrm{H}_{2}$ and stores it in the tanks. The stored energy within $\mathrm{H}_{2}$ tanks is used to run the FCs to satisfy the load needs via the time intervals of low energy produced by PV.

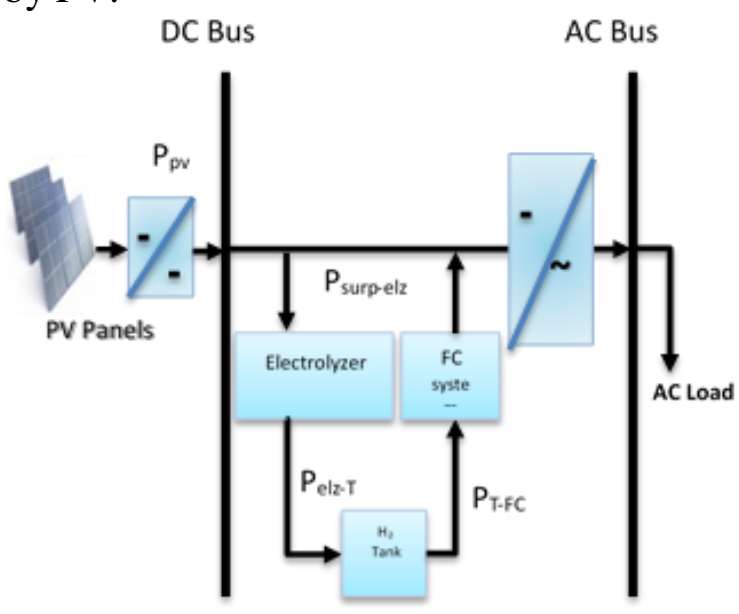

Fig. 1: The proposed PV/FC design for the studied region. 


\subsection{SOLAR PV MODEL}

For the present work, the simulation model is utilized to determine the PV module efficiency. The solar irradiation used for the studied area is located at $29^{\circ} 1^{\prime} \mathrm{N}$ latitude and $30^{\circ} 52^{\prime} \mathrm{E}$ longitude has been get using HelioClim-3 which is a database including surface solar radiation appreciated each fifteen minutes from images drawn by the Meteosat series of satellites since 2004 (14). Equation one has been applied to estimate the output of the PV modules.

$$
P_{p V}=\left(P_{\text {rated }} N_{p v} A_{m m} D_{f}\right)\left(\frac{G}{G_{r e f}}\right)\left(1+K_{T}\left(T_{C}-T_{r e f}\right)\right)
$$

Where $K_{T}=-3.7 \times 10^{-3}\left(1 /{ }^{\circ} \mathrm{C}\right)$ for poly-crystalline and mono silicon. Depending on the energy equilibrium, $T_{c}$ can be shown as follows in equation two as [21]:

$$
T_{c}=T_{a m b}+G\left(\frac{\tau \alpha}{U_{l}}\right)
$$

The overall heat loss coefficient, $\frac{\tau \pi}{\mathrm{U}_{\mathrm{l}}}$, can be expressed as the NOCT as [20]:

$$
\frac{\tau \alpha}{U_{l}}=\frac{N O C T-20}{0.8}
$$

Figure 2 shows the solar radiation of the study area while Table 1 lists the manufacture data for the PV module.

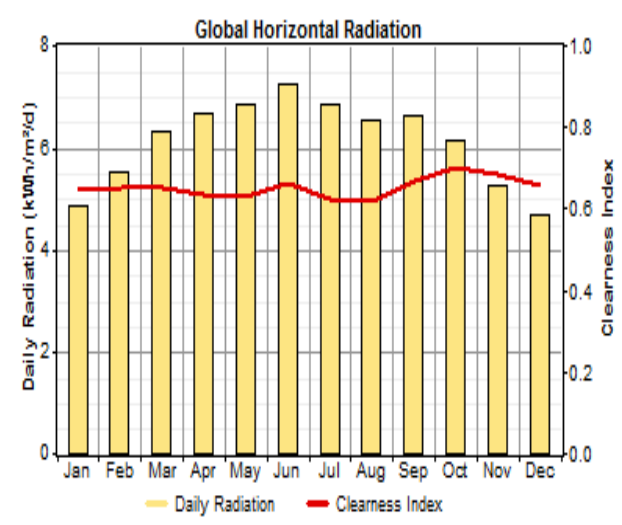

Fig. 2: Solar radiation in the studied region.
TABLE 1: MANUFACTURE DATA FOR PV MODULE

\begin{tabular}{|c|c|}
\hline Cell type & Poly-crystalline \\
\hline The NOCT & $43 \pm 2^{\circ} \mathrm{C}$ \\
\hline Module efficiency & $15.9 \%$ \\
\hline Outer dimensions (L x W x H) & $\begin{array}{c}1648 \times 990 \times 40 \\
\mathrm{~mm}\end{array}$ \\
\hline STC rated output $\left(\mathrm{P}_{\mathrm{mpp}}\right)$ & $260 \mathrm{w}_{\mathrm{p}}$ \\
\hline Derating factor & $90 \%$ \\
\hline Ground reflection & $20 \%$ \\
\hline Operating temperature & $47{ }^{\circ} \mathrm{C}$ \\
\hline
\end{tabular}

\subsection{POWER INVERTER MODEL}

The inverter is applied to change the DC output from the PV modules and the battery to $\mathrm{AC}$ power. The inverter is chosen depending on the maximum load needs. The input power of the inverter $\left(\mathrm{P}_{\mathrm{inv}}\right)$ is estimated as:

$$
P_{i n v}(t)=\frac{P_{L}(t)}{\eta_{i n v}}
$$

Technical description of the selected Inverter/Charger utilized in this work are

\begin{tabular}{|c|c|}
\hline \multicolumn{2}{|c|}{ Inverter Specifications } \\
\hline Model & MS4448PAE \\
\hline $\begin{array}{l}\text { Input battery voltage } \\
\text { range }\end{array}$ & $36.0-64.0 \mathrm{VDC}$ \\
\hline $\begin{array}{l}\text { Nominal AC output } \\
\text { voltage }\end{array}$ & $\begin{array}{c}120 / 240 \text { VAC split phase } \\
( \pm 5 \%)\end{array}$ \\
\hline $\begin{array}{c}\text { Continuous power output } \\
\text { at } 25^{\circ} \mathrm{C}\end{array}$ & 4400 VA (L-L) \\
\hline Inverter efficiency (peak) & $94 \%$ \\
\hline Waveform & Pure Sine Wave \\
\hline \multicolumn{2}{|c|}{ Charger Specifications } \\
\hline $\begin{array}{c}\text { Continuous output at } 25^{\circ} \\
\text { C }\end{array}$ & $60 \mathrm{ADC}$ \\
\hline Charger efficiency & $85 \%$ \\
\hline Power factor & $>0.95$ \\
\hline
\end{tabular}
shown in Table 2.

TABLE 2: TECHNICAL SPECIFICATIONS OF THE USED INVERTER 


\subsection{Modeling of Fuel Cell System}

In the present work, the PEM FC is used, electrolyzer hardware contains an anode, cathode, and an electrolyte. The water electrolysis happens in the electrolyzer utilizing electricity to separate water into hydrogen and oxygen. In PEM electrolyzer, the protons moves from anode to cathode via a proton exchange membrane. Transferred power from electrolyzer to $\mathrm{H}_{2}$ tank can be defined as:

$P_{\text {elz-T }}=P_{\text {surp-elz }} * \eta_{\text {elz }}$

where $P_{\text {surp }}(t)=P_{p v}(t)-P_{\text {inv }}(t)$

The energy of $\mathrm{H}_{2}$ stored in the tank at time step $t$ can be acquired by using Eq. 7:

$$
E_{H 2}(t)=E_{H 2}(t-1)+P_{e l z-T} \times \Delta \mathrm{t}(7)
$$

where $E_{H 2-\max } \leq E_{H 2} \leq E_{H 2-\min }$

The type of the $\mathrm{H}_{2}$ tank used is ultra-light composite storage cylinder with $\mathrm{H}_{2}$ capacity of 2700 (std. L), the corresponding peak energy capacity of that tank can be calculated as in Eq. 8 [22]:

$E_{H 2-\max }=0.27 \times \mathrm{H}_{2}$ heating value

Where the $\mathrm{H} 2$ heating value is 3.4 $\mathrm{kWh} / \mathrm{m} 3$ in the standard condition, the maximum storage electric capacity of the tank is $9.18 \mathrm{kWh}$ while the minimum electric capacity is set to be $5 \%$ of the maximum capacity. FCs are electrochemical equipment that change the chemical energy to electrical. The PEM FCs has reliable efficiency under discontinuous supply and is commercially obtainable at wide industrial range. This type of FCs are sufficient for large scale stationary generation and have rapid dynamic response with a power release time of 1-3 s [21]. It's output power is considered to be about $40 \%$ and computed as:

$$
P_{F C}=P_{T-F C} * \eta_{F C}
$$

\subsection{LOAD PROFILE MOdEL}

An annual hourly load profile is simulated using the average daily load demand of the studied zone. The load profile was created using micro power optimization and simulation software tool Homer® $[22,23]$. To account for the random variations of the hourly and daily loads, random noise was added to the average daily load to create the annual load profile. Figure 3 illustrates the daily profile of the load demand that used in the studied region.

\section{PROBLEM FORMULATION}

The goal of this manuscript is to introduce an efficient, cost-effective and credible isolated micro-grid based on PV and FCs. This have been reached via optimizing the number of PV modules, FCs, electrolyzers and the $\mathrm{H} 2$ storage tanks, which are looked as the main ruling parameters of the task.

\subsection{OBJECTIVE FUNCTION AND CONSTRAINTS}

The aim of the optimization is to minimize the TNPV, and maximize the reliability of the system, proved as LPSP, and preservation the EXC of the system as lesser as possible. In this case, four continuous ruling parameters of $\mathrm{N}_{\mathrm{pV}}, \mathrm{N}_{\mathrm{FC}}$, $\mathrm{N}_{\mathrm{Elz}}$ and $\mathrm{N}_{\mathrm{H} 2 \mathrm{~T}}$ must be optimized.

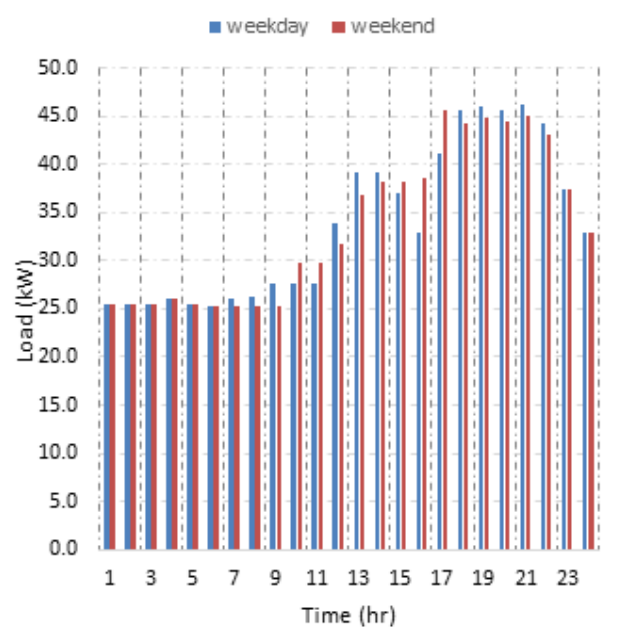

Fig. 3: The daily load profile of the studied area. 
The objective function is introduced in Eq. 10, subject to the constraints in Eqs. 11 15. Subject to:

\section{Objective function}

$$
\begin{gathered}
=\min . T N P V\left(N_{P V}, N_{F C}, N_{E l z}, N_{H 2 T}\right) \\
0 \leq N_{P V} \leq N_{P V}^{\max } \\
0 \leq N_{F C} \leq N_{F C}^{\max } \\
0 \leq N_{E l z} \leq N_{E l z}^{\max } \\
0 \leq N_{H 2 T} \leq N_{H 2 T}^{\max } \\
L P S P \leq L P S P_{\max }
\end{gathered}
$$

Where: $L P S P_{\max }$ is the peak permissible LPSP given.

\subsection{The Proposed System STRATEgY}

In this work, the suggested model is based on two variables. The first parameter is the LPSP with the following constraints:

$$
0 \leq \text { LPSP } \leq 1 \text {, }
$$

The LPSP is equal zero when the load demands is fully supplied, and equal one when the load demands is not supplied [24]. The second parameter is the EXC. The introduced techniques lookup the optimal grouping of the PV modules, the FCs, the electrolyzers and the $\mathrm{H}_{2}$ storage tanks that reduces the cost of the LPSP and the EXC. The procedures for the working design can be brief in the followings:

1. At $\mathrm{t}=1$, the $\mathrm{H}_{2}$ tank is empty.

2. The overall output power of the PV modules at each hour is estimated as in Eq. 1.

3. The inverter input power $P_{\text {inv }}(t)$ is computed as in Eq. 4.

Three Scenarios of the introduced system are executed:

a. Generation Meets Demand: b. If $P_{p v}(t)=P_{i n v}(t)$, then the $\mathrm{H}_{2}$ tanks storage capacity remains unchanged, and $\operatorname{LPS}(t)=0$.

c. Excess Generation:

If $\mathrm{P}_{\mathrm{pv}}(\mathrm{t})>\mathrm{P}_{\mathrm{inv}}(\mathrm{t})$, then the excess power can be applied to charge the electrolyzers, the new storage capacity is estimated utilizing Eq. 7. If the SOC of the $\mathrm{H}_{2}$ tanks reaches its peak border, the rest of the increased power is looked as wasted energy $\mathrm{W}_{\mathrm{E}}(\mathrm{t})$ and will be used in a dump load, LPS $(\mathrm{t})=0$.

$$
W E(t)=P_{\text {surp }}(t)-\left(E_{H 2-\max }-E_{H 2}(t-1)\right)
$$

d. Excess Demand:

If $\mathrm{P}_{\mathrm{pv}}(\mathrm{t})<\mathrm{P}_{\mathrm{inv}}(\mathrm{t})$, then $\mathrm{H}_{2}$ tanks is utilzied to satisfy the power deficit, and the new storage capacity is as:

$$
\begin{aligned}
& P_{\text {atf }}(t)=P_{\mathrm{sinv}}(t)-P_{\mathrm{pw}}(\mathrm{t}) \\
& E_{n 2}(t)=E_{n 2}(t-1)-P_{d t f} X \eta_{\mathrm{FC}} \times \Delta t \\
& \operatorname{LPS}(t)=P_{L}(t)-\left(P_{m 2}(t)+E_{m 2}(t-1)-E_{n 2}-\min \right)(19)
\end{aligned}
$$

4. The LPSP for a specific period $\mathrm{T}$, is computed as:

$$
\operatorname{LPSP}(t)=\sum_{t=1}^{T} \frac{\operatorname{LPS}(t)}{P_{L}(t)}, T=8760
$$

5. The EXC, for a specific period $\mathrm{T}$, is defined as:

$$
\operatorname{EXC}(t)=\sum_{t=1}^{T} \frac{W E(t)}{P_{r \varepsilon}(t)}, T=8760
$$

For one year study time and recognized value of the LPSP, different configurations have been covered the load needs in a reliable manner. Finally the optimum configuration can be given as a function of the LCOE. This can be completed by applying the economic model. 


\section{ECONOMICAL AND OPTIMIZATION MODEL}

The economic model is sophisticated for the suggested system related to the TNPV, and the LCOE values. The LCOE is computed using $(4,25,26)$ :

$$
\begin{aligned}
& \mathrm{LCOE}=\frac{T N P V \times C R F}{E_{\text {load }}} \\
& C R F=\frac{i\left(1+I_{\text {real }}\right)^{R_{\text {proj }}}}{\left(1+I_{\text {real }}\right)^{R_{\text {proj }}-1}}
\end{aligned}
$$

Where $I_{\text {real }}$ is computed by Fisher's formula $(4,25,26)$ :

$$
I_{\text {real }}=\frac{i+I_{f}}{1+I_{f}}
$$

and the TNPV is calculated using the followings $(25,26)$ :

$$
T N P V=C_{P V}+C_{F C}+C_{E l z}+C_{H 2 T}
$$

Where $C_{P V}, C_{F C}, C_{E l z}$ and $C_{H 2 T}$ are the cost per unit of the PV system, the FC, the electrolyzer and the $\mathrm{H}_{2}$ storage tank respectively. Each component cost can be computed as:

$$
C=C_{I}+C_{R}+C_{\text {O\&M }}-S
$$

Where: $\mathrm{C}_{\mathrm{I}}$ contains the BOS, the system design, Co\&M contains the operator's salaries, inspections, the insurance and the scheduled maintenance costs. It has been considered, the salvage value (S) based on $C_{R}$ rather than $C_{I}$. S is estimated by:

$$
S=C_{R}\left(\frac{R_{\text {rem }}}{R_{\text {comp }}}\right)
$$

Where: $R_{\text {rem }}$ is calculated using the following equations:

$$
R_{\text {rem }}=R_{\text {comp }}-\left(R_{\text {proj }}-R_{\text {rep }}\right)
$$

$$
R_{r e p}=R_{\text {comp }} \times I N T\left(\frac{R_{\text {proj }}}{R_{\text {comp }}}\right)
$$

$I N T=$ a function that returns the integer amount of a real number. The initial capital costs can be estimated from the information given in Table 3 .

TABLE 3: COSTS AND OTHER PARAMETERS FOR ECONOMIC ANALYSIS

\begin{tabular}{|l|c|c|c|c|c|}
\cline { 2 - 6 } \multicolumn{1}{c|}{} & unit & $\begin{array}{c}\text { PV } \\
\text { Solar } \\
\text { System }\end{array}$ & $\begin{array}{c}\text { Fuel } \\
\text { cell }\end{array}$ & Electrolyzer & $\begin{array}{c}\mathrm{H} 2 \\
\text { tanks }\end{array}$ \\
\hline Capacity & $\mathrm{kWh}$ & 5.46 & 5 & 5 & 9.81 \\
\hline Life time & years & 20 & 5 & 5 & 20 \\
\hline Initial cost & $\$$ & 15,465 & 22,427 & 9800 & 4770 \\
\hline $\begin{array}{l}\text { Replacement } \\
\text { cost }\end{array}$ & $\$$ & 6,573 & 15,699 & 6860 & 4770 \\
\hline $\begin{array}{l}\text { Operation } \\
\text { and } \\
\text { maintenance } \\
\text { cost }\end{array}$ & $\$$ & 50 & 50 & 20 & 10 \\
\hline
\end{tabular}

\section{FLOWER POLLINATION ALGORITHM}

The FPA has been introduced by Xin-She Yang has in 2012, which is a mimic of the pollination method of flowering plants (26, 27, 28). Pollination can be accomplished by self-pollination or cross-pollination. The algorithm has benn illustrated in the following flowchart of Figure 4. Via MatlabTM package, the numerical simulation outputs acquired by the FPA algorithm have been compared to the corresponding results while using the $\mathrm{ABC}$. The parameters of the FPA and ABC algorithms are listed in Table 4.

TABLE 4: PARAMETERS OF THE ABC AND FPA ALGORITHMS

\begin{tabular}{|l|c|c|}
\hline \multicolumn{1}{|c|}{ Algorithm } & ABC & FPA \\
\hline Number of iterations & 100 & 100 \\
\hline Population Size & 25 & 25 \\
\hline $\begin{array}{l}\text { Dimension of the } \\
\text { search variables }\end{array}$ & 4 & 4 \\
\hline Probability switch & & 0.8 \\
\hline
\end{tabular}




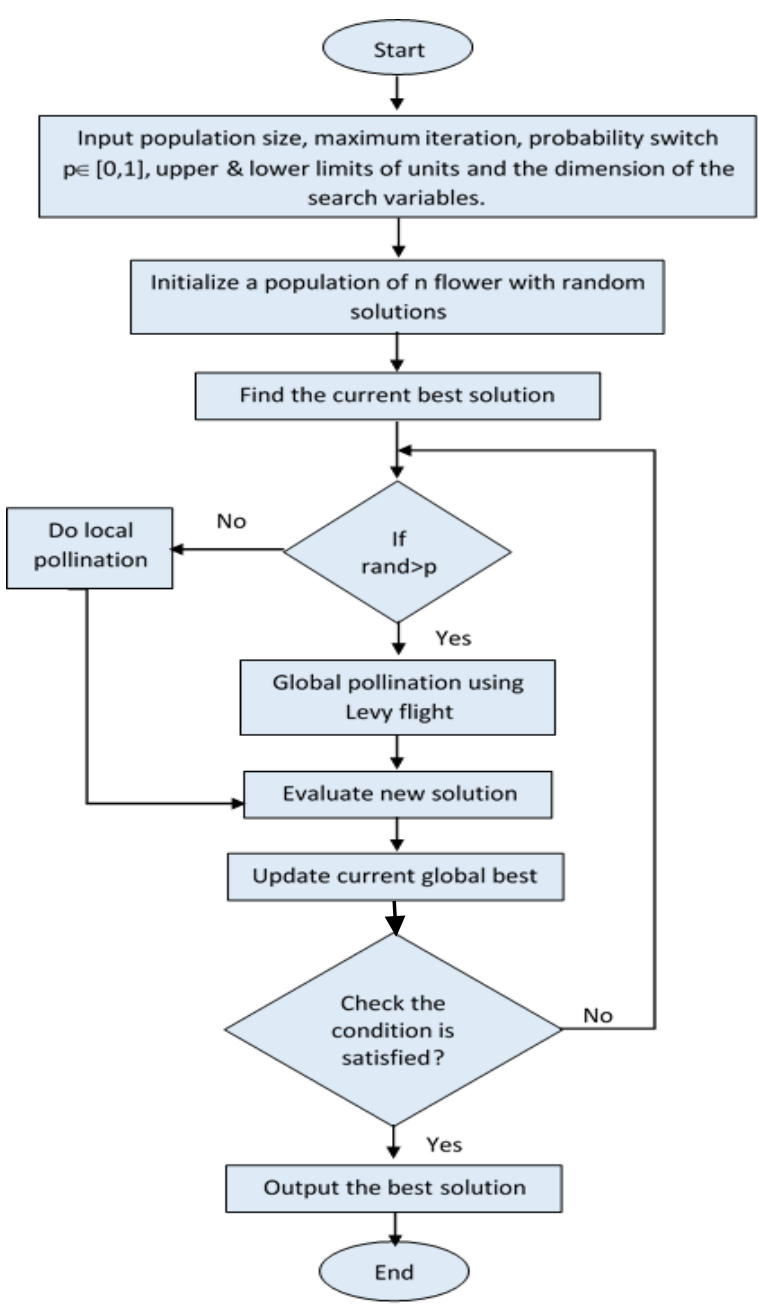

Fig.4: The flowchart of the FPA technique.

\section{RESULTS AND DISCUSSIONS}

The simulation time step is considered to be one hour and runs data for one year. The obtained outputs from the FPA are taken as a reference for comparison purposes. The peak border of the LPSP $=$ $2 \%$ has been considered in this work. The optimal solution obtained for this limit for the two algorithms are shown in Table 5. The optimal solution ranked on the basis of the TNPV. Table 5 indicates that, when the LPSP of $1.69 \%$, the system should be designed to work at a low TNPV of $\$ 3,479,022$ and the LCOE of $0.708 \$ / \mathrm{kWh}$. Again, for this LPSP value, the EXC of the system is to be $3.84 \%$. The results from Table 5 clearly indicate that both FPA and $\mathrm{ABC}$ find convergent optimized solutions, but the FPA is satisfactory as compared to the $\mathrm{ABC}$ in terms of simulation time and outputs.

TABLE 5: OPTIMAL SIZING OUTPUTS DRAWN FROM THE FPA AND THE ABC

\begin{tabular}{|c|c|c|}
\hline Algorithm & FPA & ABC \\
\hline LPSP & $1.69 \%$ & $1.92 \%$ \\
\hline EXE & $3.84 \%$ & $3.22 \%$ \\
\hline LCOE & 0.708 & 0.723 \\
\hline TNPC & $3,479,022$ & $3,555,807$ \\
\hline Total annual cost & $\mathbf{2 0 9 , 0 5 1}$ & $\mathbf{2 1 3 , 6 6 5}$ \\
\hline Npv & 21 & 20 \\
\hline $\mathrm{N}_{\mathrm{H} 2 \mathrm{~T}}$ & 38 & 39 \\
\hline
\end{tabular}

The FPA predicts 21 solar PV panels, 28 FCs, 60 electrolyzers and $38 \mathrm{H} 2$ storage tanks. Figure 5 illustrates the comparison between the FPA and the ABC convergence for LPSP of $2 \%$. The outputs illustrate the quick convergence of the introduced technique to the optimal arrangement relative to $\mathrm{ABC}$ convergence. Lengthy discounted cash flow is illustrated in Figure 6 and 7 shows the assistance of the costs of each equipment to the TNPV of the optimized design.

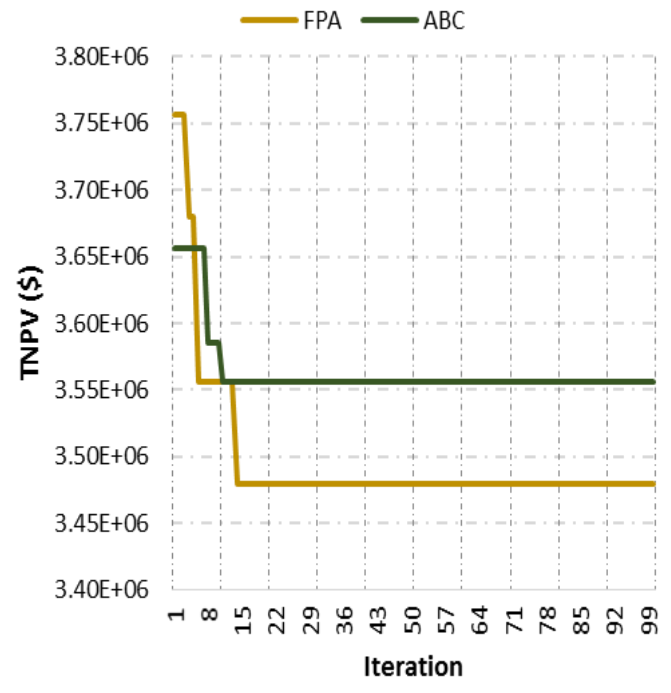

Fig. 5: Comparison of convergence rates for the FPA and the $\mathrm{ABC}$ techniques at LPSP $=2 \%$.

It is cleared that, the FC system has the highest capital, replacement costs of $(\$ 627,956)$ and $(\$ 1,436,470)$ respectively. Figure 8 shows that the portion of the PV, 
the $\mathrm{FC}$, the electrolyzer and the $\mathrm{H}_{2}$ storage tank annualized costs from the TNPC of the optimized system. Different sensitivity analysis has been behaved to portend the future efficiency of the system. Three variables are assumed: the changing of the initial cost of the FC, the electrolyzer and the $\mathrm{H}_{2}$ storage tank. Figure 9 shows the effect of the cost variation of the FC system from $50 \%$ to $125 \%$ of the present cost used in this study on the LCOE. From Fig. 8, the changing of the FC system has the major effect on the LCOE compared than the cost of the electrolyzer and the $\mathrm{H}_{2}$ storage tank. The LCOE increases from $0.5054 \$ / \mathrm{kWh}$ to $0.7075 \$ / \mathrm{kWh}$ for the FC system initial cost of 11213.5 \$/unit and of 22427 \$/unit respectively. This means that decreasing the FC system initial cost by $50 \%$, the LCOE is reduced to $28.57 \%$. For the same decrease in the initial cost of the electrolyzer and the $\mathrm{H}_{2}$ storage tank, the LCOE is decreased by $13.13 \%$ and $2.63 \%$ respectively.

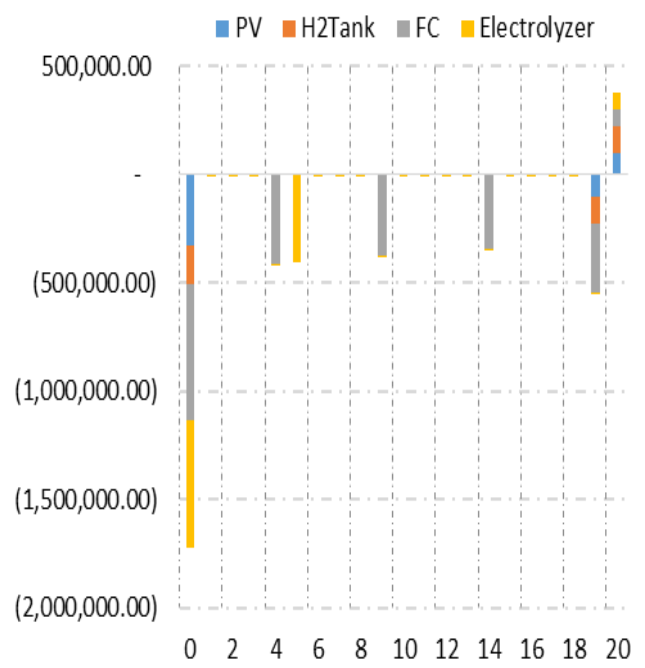

Fig. 6: The discounted cash flow of the optimized system

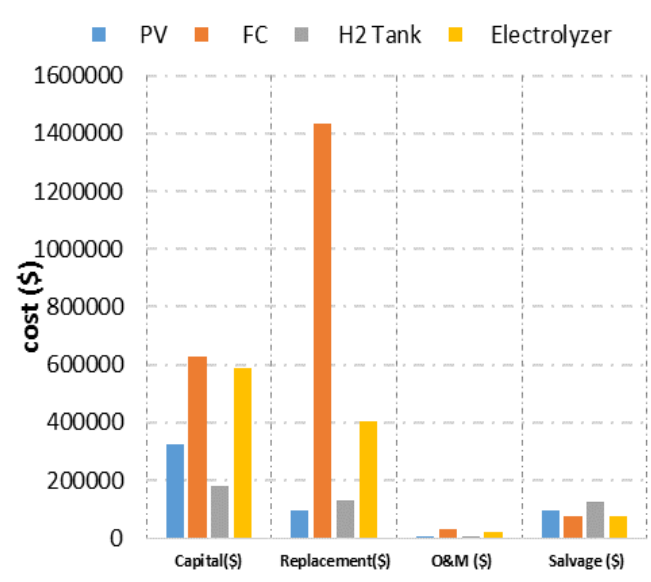

Fig. 7: The breakdown of the TNPC of the optimum HPBRS components

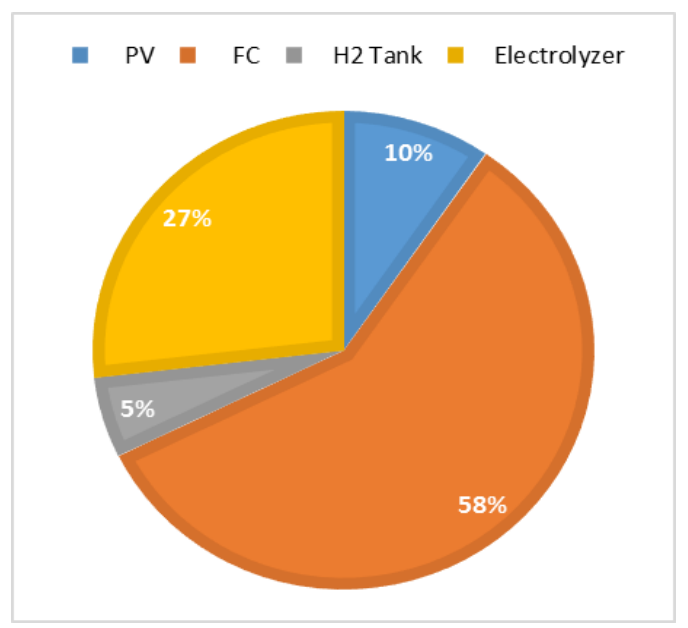

Fig. 8: The percentage of the optimized system components annualized costs in the TNPV

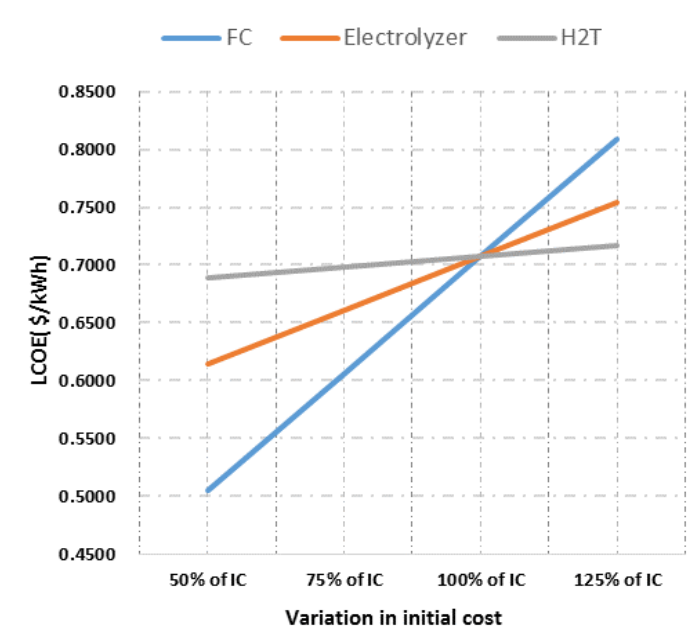

Fig. 9: Impact of the changing of the FC, electrolyzer and $\mathrm{H}_{2}$ tank cost on the LCOE of the system 


\section{CONCLUSION}

This paper introduces an effective technique to design an island micro-grid based on PV and FC. The proposed design optimizes the size of each device including a reliable power feeding depending on the LPSP, and reducing the TNPV of the system. The main contribution of the proposed design is the implementation of the FPA, which proved to show superior performance when compared to the $\mathrm{ABC}$ algorithm. A sensitivity analyses has been done assuming the changing in the cost of the $\mathrm{FC}$, the electrolyzer and the $\mathrm{H}_{2}$ storage tank. These chosen parameters are highly influence the development decisions, as their changing will affect the long-range sustainability of the system. The introduced design is utilized as a tool to prove its economic, ecological and social effort in covering the existing and the future energy needs.

\section{NOMENCLATURE}

\begin{tabular}{|l|l|}
\hline Am & Area of a single module (m2) \\
\hline ABC & Artificial Bee Colony \\
\hline BOS & Balance Of System \\
\hline CI & System components initial capital cost $(\$)$ \\
\hline CO\&M & Operation and maintenance costs $(\$)$ \\
\hline CR & System components replacement cost $(\$)$ \\
\hline CRF & Capital Recovery Factor \\
\hline Df & Photovoltaic derating factor $(0.8)$ \\
\hline SEC & Saudi Electricity Company \\
\hline EXC & $\begin{array}{l}\text { Percentage of the Excess Energy } \\
\text { tank }\end{array}$ \\
\hline Eh2 & The energy of hydrogen stored in the tank \\
\hline Eho
\end{tabular}

\begin{tabular}{|l|l|}
\hline FPA & Flower Pollination Algorithm \\
\hline GHG & Greenhouse Gases \\
\hline G & $\begin{array}{l}\text { Global irradiance fallen on the titled plane } \\
\text { kW/m2) }\end{array}$ \\
\hline Gref & $\begin{array}{l}\text { Solar irradiation at base conditions } \\
\text { kW/m2) }\end{array}$ \\
\hline GA & Genetic Algorithm \\
\hline H2 & Hydrogen chemical symbol \\
\hline NH2T & Number of H2 storage tanks \\
\hline i & Interest rate \\
\hline If & Inflation rate \\
\hline Ireal & Real interest rate \\
\hline KT & Maximum power temperature coefficient \\
\hline PCOE & Levelized Cost Of Energy \\
\hline Prate & Power \\
\hline PHV & Lower Heating Value \\
\hline LPSP & Loss of Power Supply Probability \\
\hline NOCT & Normal Operating Cell Temperature \\
\hline NPV & Numberanger Membrane \\
\hline to the H2 tank
\end{tabular}




\begin{tabular}{|l|l|}
\hline Rrem & $\begin{array}{l}\text { Remaining life of the equipment at the finish } \\
\text { of the project lifetime (year) }\end{array}$ \\
\hline Rrep & Duration of replacement cost (year) \\
\hline S & System component salvage value $(\$)$ \\
\hline SEC & Saudi Electricity Company \\
\hline SOC & State Of Charge \\
\hline TAC & Total Annual Cost \\
\hline Tamb & Ambient temperature $\left({ }^{\circ} \mathrm{C}\right)$ \\
\hline TNPV & Total Net Present Value \\
\hline Tc & Photovoltaic cell temperature $\left({ }^{\circ} \mathrm{C}\right)$ \\
\hline Tref & Reference condition temperature $\left({ }^{\circ} \mathrm{C}\right)$ \\
\hline Ul & Coefficient of overall heat loss $\left(\mathrm{w} / \mathrm{m} 2 /{ }^{\circ} \mathrm{C}\right)$ \\
\hline$\tau$ & Photovoltaic cell transmittance coefficient \\
\hline$\eta_{\mathrm{a} l \mathrm{~s}}$ & Efficiency of the electrolyzer \\
\hline$\alpha$ & $\begin{array}{l}\text { Absorption coefficient of the photovoltaic } \\
\text { cells }\end{array}$ \\
\hline$\eta$ inv & Efficiency of the inverter \\
\hline
\end{tabular}

\section{REFERENCES}

[1] C. L. Azimoh, P. Klintenberg, F. Wallin, B. Karlsson, and C. Mbohwa, "Electricity for development: Mini-grid solution for rural electrification in South Africa," Energy Convers. Manag., vol. 110, pp. 268-277, 2016.

[2] A. Giwa, A. Alabi, A. Yusuf, and T. Olukan, "A comprehensive review on biomass and solar energy for sustainable energy generation in Nigeria," Renew. Sustain. Energy Rev., vol. 69, pp. 620-641, Mar. 2017.

[3] S. Barakat, M. M. Samy, M. B. Eteiba, and W. I. Wahba, ". Optimization of an Off-Grid PV/Biomass Hybrid System with Different Battery Technologies. Volume 40, July 2018, Pages 713-727, https://doi.org/10.1016/j.scs.2018.01.012. 2018.

[4] S. Singh, M. Singh, and S. C. Kaushik, "Feasibility study of an islanded microgrid in rural area consisting of PV, wind, biomass and battery energy storage system," Energy
Convers. Manag., vol. 128, pp. 178-190, Nov. 2016

[5] C. M. I. Hussain, B. Norton, and A. Duffy, "Technological assessment of different solarbiomass systems for hybrid power generation in Europe," Renew. Sustain. Energy Rev., vol. 68, pp. 1115-1129, Feb. 2017.

[6] M. Kalantar and S. M. Mousavi G., "Dynamic behavior of a stand-alone hybrid power generation system of wind turbine, microturbine, solar array and battery storage," Appl. Energy, vol. 87, no. 10, pp. 3051-3064, 2010.

[7] E. Koutroulis, D. Kolokotsa, A. Potirakis, and K. Kalaitzakis, "Methodology for optimal sizing of stand-alone photovoltaic/windgenerator systems using genetic algorithms," Sol. energy, vol. 80, no. 9, pp. 1072-1088, 2006.

[8] P. Paliwal, N. P. Patidar, and R. K. Nema, "Determination of reliability constrained optimal resource mix for an autonomous hybrid power system using Particle Swarm Optimization," Renew. Energy, vol. 63, pp. 194-204, Mar. 2014.

[9] M. Sharafi and T. Y. ELMekkawy, "Multiobjective optimal design of hybrid renewable energy systems using PSO-simulation based approach," Renew. Energy, vol. 68, pp. 67-79, Aug. 2014.

[10] M. Tahani, N. Babayan, and A. Pouyaei, "Optimization of PV/Wind/Battery standalone system, using hybrid FPA/SA algorithm and CFD simulation, case study: Tehran," Energy Convers. Manag., vol. 106, pp. 644659, Dec. 2015.

[11] E. S. Oda, A. A. Abdelsalam, M. N. AbdelWahab, and M. M. El-Saadawi, "Distributed generations planning using flower pollination algorithm for enhancing distribution system voltage stability," Ain Shams Eng. J., Dec. 2015.

[12] D. F. Alam, D. A. Yousri, and M. B. Eteiba, "Flower pollination algorithm based solar PV parameter estimation," Energy Convers. Manag., vol. 101, pp. 410-422, 2015.

[13] H. A. M. Fathi, E. Beshr, and M. B. Eteiba, "Multi-Objective optimization of islanded microgrids," Electrical, Computer and Communication Technologies (ICECCT), 2015 IEEE International Conference on, 2015, pp. 1-7.

[14] M. M. Samy, S. Barakat. H. H. Sarhan and, S. A. Al-Ghamdi. " A Hybrid PV-Biomass Generation Based Micro-Grid for the 
Irrigation System of a Major Land Reclamation Project in Kingdom of Saudi Arabia (KSA) - Case Study of Albaha Area" Proceeding of the $18^{\text {th }}$ IEEE International Conference on Environment and Electrical Engineering, Palrmo, Italy June 12 -15, 2018.

[15] V. Dash and P. Bajpai, "Power management control strategy for a stand-alone solar photovoltaic-fuel cell--battery hybrid system," Sustain. Energy Technol. Assessments, vol. 9, pp. 68-80, 2015.

[16] S. Saravanan and S. Thangavel, "Instantaneous reference current scheme based power management system for a solar/wind/fuel cell fed hybrid power supply," Int. J. Electr. Power Energy Syst., vol. 55, pp. 155-170, 2014.

[17] P.C. Chen, "Configuration of solar-hydrogen mild hybrid fuel cell power systems for electric vehicles," J. Power Sources, vol. 201, pp. 243-252, 2012.

[18] D. Bezmalinović, F. Barbir, and I. Tolj, "Techno-economic analysis of PEM fuel cells role in photovoltaic-based systems for the remote base stations," Int. J. Hydrogen Energy, vol. 38, no. 1, pp. 417-425, 2013.

[19] H. Chiroma, N. L. M. Shuib, S. A. Muaz, A. I. Abubakar, L. B. Ila, and J. Z. Maitama, "A review of the applications of bio-inspired Flower Pollination Algorithm," Procedia Comput. Sci., vol. 62, no. Scse, pp. 435-441, 2015.

[20] M. S. Ismail, M. Moghavvemi, and T. M. I. Mahlia, "Techno-economic analysis of an optimized photovoltaic and diesel generator hybrid power system for remote houses in a tropical climate," Energy Convers. Manag., vol. 69, pp. 163-173, 2013.
[21] R. S. Garcia and D. Weisser, "A wind--diesel system with hydrogen storage: Joint optimisation of design and dispatch," Renew. energy, vol. 31, no. 14, pp. 2296-2320, 2006.

[22] S. Barakat, M. M. Samy, M. B. Eteiba, and W. I. Wahba, "Viability study of grid connected PV/Wind/Biomass hybrid energy system for a small village in Egypt," in Power Systems Conference (MEPCON), 2016 Eighteenth International Middle East, 2016, pp. 46-51.

[23] S. Barakat, M. M. Samy, M. B. Eteiba, and W. I. Wahba, "Feasibility Study of Grid Connected PV-Biomass Integrated Energy System in Egypt," Int. J. Emerg. Electr. Power Syst., vol. 17, no. 5, 2016.

[24] H. Yang, W. Zhou, L. Lu, and Z. Fang, "Optimal sizing method for stand-alone hybrid solar--wind system with LPSP technology by using genetic algorithm," Sol. energy, vol. 82, no. 4, pp. 354-367, 2008.

[25] B. Leland, and Anthony Tarquin "Engineering economy," $7^{\text {th }}$ edition 2012.

[26] M. M. Samy, Shimaa Barakat and H. S. Ramadan, "A Flower Pollination Optimization Algorithm for an Off-Grid PV-Fuel Cell Hybrid Renewable System," Accpted for publication on the International Journal of Hydrogen Energy (IJHE), 24 May, 2018.

[27] Nahar Alshammar, M. M.Samy and Johnson Asumadu "Optimal Economic Analysis Study for Renewable Energy Systems to Electrify Remote Region in Kingdom of Saudi Arabia”, Proceeding of the $20^{\text {th }}$ IEEE Middle East Power Systems Conference (MEPCON), Cairo, Egypt, Dec 18 -20, 2018.

[28] X.-S. Yang, "Flower pollination algorithm for global optimization," in International Conference on Unconventional Computing and Natural Computation, 2012, pp. 240-249. 